\title{
SPÓŁDZIELNIA SOCJALNA JAKO FORMA ŁAGODZENIA BEZROBOCIA I AKTYWIZACJI OSÓB NIEPEŁNOSPRAWNYCH
}

\section{SPÓŁDZIELNIE SOCJALNE JAKO SZCZEGÓLNY TYP SPÓŁDZIELNI PRACY I ICH RODOWÓD}

Pojęcie spółdzielni socjalnej i jej początkowa regulacja prawna jest ściśle związana z uchwaleniem i wejściem w życie ustawy z 20 kwietnia $2004 \mathrm{r}$. o promocji zatrudnienia i instytucjach rynku pracy ${ }^{1}$. Na podstawie art. 127 pkt 3b powołanej ustawy dokonano zmiany ustawy z 16 września 1982 r. Prawo spółdzielcze ${ }^{2}$, dodając w Tytule II przepisy art. 203a-203d, jako dodatkowy Dział V Prawa spółdzielczego.

Przed dokonaniem powyższych zmian rolę i zadania aktywizacji zawodowej i rehabilitacji zawodowej na gruncie rozwiązań prawnospółdzielczych spełniały przepisy Prawa spółdzielczego dotyczące spółdzielni pracy, a w szczególności te, które były adresowane do spółdzielni inwalidów i spółdzielni niewidomych oraz ich członków. Rolę instrumentów ułatwiających integrację zawodową i społeczną rehabilitację członków wspomnianych spółdzielni miały między innymi spełniać przepisy rozporządzenia wykonawczego do art. 181a § 4 Prawa spółdzielczego zgodnie z nimi, Rada Ministrów ustanawiać miała dla tych spółdzielni wyłączne prawo do wytwarzania niektórych wyrobów i świadczenia niektórych usług oraz określać, w jakim zakresie może być prowadzona tego rodzaju działalność gospodarcza przez innych przedsiębiorców. Powołany przepis został uchylony na mocy regulacji ustawowej służącej przeciwdziałaniu praktykom monopolistycznym oraz ochronie interesów konsumentów ${ }^{3}$. Rozwiązaniem ułatwiającym realizację celów integracyjnych oraz rehabilitacyjnych jest w dalszym ciągu przyjęta w art. 201 Prawa spółdzielczego możliwość ustalenia $\mathrm{w}$ statucie spółdzielni pracy, a przede wszystkim spółdzielni inwalidów lub niewidomych, możliwości zatrudniania członków na podstawie umów o pracę nakładczą oraz w oparciu o cywilnoprawne umowy zlecenia lub o dzieło. Wykorzystanie wspomnianych elastycznych form zatrudnienia pozwala na świadczenie pracy osobom niepełnosprawnym w stopniu uniemożliwiającym

\footnotetext{
${ }^{1}$ Dz. U. 2000, Nr 99, poz. 1001 z późn. zm.

${ }^{2}$ Tekst jedn.: Dz. U. 2003, Nr 188, poz. 1848 z późn. zm.

${ }^{3}$ Por. art. 5 ust. 1 ustawy z 24 lutego 1990 r. o przeciwdziałaniu praktykom monopolistycznym, Dz. U. 1999, Nr 52, poz. 547 oraz art. 2 ustawy z 7 lipca 1994 r. o zmianie ustawy - Prawo spółdzielcze oraz o zmianie niektórych innych ustaw, Dz. U. 1994, Nr 90, poz. 419.
} 
lub co najmniej utrudniajacym wykonywanie pracy na warunkach typowego, umownego stosunku pracy. Już od wielu lat, a ściślej od połowy lat 90. XX w., dostrzegalny jest proces spadku ilościowego spółdzielni inwalidów i niewidomych, a co za tym idzie - znaczącego obniżenia liczby zdolnych w określonym stopniu i skłonnych do podjęcia pracy osób niepełnosprawnych. Zjawisko to zdeterminowane jest różnymi przyczynami. Do nich należy między innymi wspierana regulacjami prawnymi koncepcja zakładów pracy chronionej, nader często realizowana niemal wyłącznie $\mathrm{z}$ racji preferencji podatkowych przy równoczesnej tendencji maksymalnego ograniczenia liczby zatrudnianych osób niepełnosprawnych. Z pewnością też część omawianych spółdzielni nie zdołała dostosować się do rynkowych reguł konkurencji ze strony zdecydowanie silniejszych ekonomicznie przedsiębiorców niezwiązanych rygorami dotyczącymi zatrudniania osób niepełnosprawnych.

Idea spółdzielni socjalnych, wyrażona najpierw w ustawie z 2004 r. o promocji zatrudnienia, a następnie w art. 203a-203d Prawa spółdzielczego, przynajmniej w założeniach wykracza poza cele charakteryzujące spółdzielnie inwalidów oraz spółdzielnie niewidomych. Aktualnie obowiązujący kształt wspomnianej idei i jej założeniom nadała ustawa z 27 kwietnia 2006 r. o spółdzielniach socjalnych ${ }^{4}$.

\section{ZAŁOŻENIE, CZŁONKOSTWO I ZATRUDNIENIE W SPÓŁDZIELNI SOCJALNEJ}

Ustawa - Prawo spółdzielcze w brzmieniu obowiązującym do $1994 \mathrm{r}$. przewidywała dostępność członkostwa, w tym również możliwość współzałożycielstwa spółdzielni nie tylko dla osób fizycznych i prawnych, ale również dla organizacji politycznych nieposiadających osobowości prawnej. Nowelizacja powyższej ustawy dokonana ustawą z 7 lipca $1994 \mathrm{r} .{ }^{5}$ ograniczyła zarówno krag podmiotów zakładających, jak i przystępujących do spółdzielni wyłącznie do osób fizycznych i prawnych ${ }^{6}$. Powyższy stan prawny utrzymany był $\mathrm{w}$ odniesieniu do wszystkich typów spółdzielni do chwili wejścia w życie ustawy z 27 kwietnia 2006 r. o spółdzielniach socjalnych ${ }^{7}$. W myśl powołanej ustawy konstrukcja spółdzielni socjalnej, a w konsekwencji możliwość jej założenia przewidziana jest dla określonych kategorii osób fizycznych znajdujących się w szczególnie trudnej sytuacji materialnej, a więc osób bezrobotnych, osób niepełnosprawnych oraz spełniających warunki objęcia pieczą $\mathrm{w}$ ramach zatrudnienia socjalnego ${ }^{8}$. Poprzedzające ustawę z 27 kwietnia 2006 r. unormo-

\footnotetext{
${ }^{4}$ Dz. U. 2006, Nr 94, poz. 651 z późn. zm.

${ }^{5}$ Szerzej w tej sprawie zob. Z. Niedbała, Komentarz do znowelizowanego prawa spótdzielczego, Poznań 1994, s. 20-21.

${ }^{6}$ Por. art. 15 Prawa spółdzielczego.

${ }^{7}$ Z uwzględnieniem zmian opublikowanych w: Dz. U. 2009, Nr 91, poz. 742 oraz Dz. U. 2010, Nr 28, poz. 146.

${ }^{8}$ Dotyczy to osób wskazanych w art. 1 ust. 2 pkt 1-4, 6 i 7 ustawy z 13 czerwca 2003 r. o zatrudnieniu socjalnym, Dz. U. 2003, Nr 122, poz. 1143 z późn. zm.
} 
wania zawarte w art. 203a Prawa spółdzielczego rezerwowały prawo zakładania i przystępowania do spółdzielni socjalnych wyłącznie dla osób fizycznych należących do wskazanych wyżej kategorii. Ustawa z $2006 \mathrm{r}$. wydatnie rozszerzyła krąg podmiotów uprawnionych do nabycia statusu członkowskiego $\mathrm{w}$ spółdzielni socjalnej zarówno $\mathrm{w}$ trybie założycielskim, jak i przez przystąpienie do istniejącej spółdzielni. Możliwość taką uzyskały:

- inne osoby fizyczne niespełniające warunków zaliczenia do jednej z kategorii wymienionych $\mathrm{w}$ art. 3 ust. 1 ustawy z 2006 r., z zastrzeżeniem, że nie mogą one stanowić więcej niż 50\% ogólnej liczby założycieli,

- organizacje pozarządowe w rozumieniu przepisów o działalności pożytku publicznego i o wolontariacie lub jednostki samorządu terytorialnego,

- kościelne osoby prawne.

Wydatne rozszerzenie kręgu podmiotów korzystających z prawa zakładania i przystępowania do spółdzielni socjalnych - jak można sądzić - miało zdynamizować procesy założycielskie i stanowić istotną pomoc dla osób pozbawionych z różnych przyczyn innych szans zatrudnienia pracowniczego. Realizacji takich celów w znacznym zakresie może służyć dostępność członkostwa w spółdzielni socjalnej tak zwanych innych osób fizycznych. Można bowiem założyć, że niejednokrotnie wśród założycieli bezrobotnych i niepełnosprawnych nie będzie osób legitymujących się kwalifikacjami zawodowymi niezbędnymi do efektywnego prowadzenia działalności gospodarczej oznaczonej w statucie spółdzielni. Mając jednak na uwadze podstawowe cele społeczne kreowania typu spółdzielni socjalnych (społeczna i zawodowa reintegracja jej członków ${ }^{9}$ ), można sądzić, że bardziej ich realizacji służyło rozwiązanie przyjęte w uchylonym art. 203b § 2 Prawa spółdzielczego. Przepis ten stwarzał możliwość zatrudniania również innych osób fizycznych niż taksatywnie wskazane w art. 203a $\S 1$, ale bez równoczesnego członkostwa $\mathrm{w}$ spółdzielni socjalnej, tym bardziej że ustawa z 2006 r. w art. 12 ust. 1a przewiduje możliwość zatrudniania w spółdzielni socjalnej osób niebędacych jej członkami ${ }^{10}$. Natomiast równoczesne członkostwo i zatrudnienie w spółdzielni socjalnej tak zwanych innych osób stwarza pewne obawy przed zdominowaniem przez tę grupę - zwykle lepiej przygotowana zawodowo i mniej zainteresowaną wspomnianymi celami społecznymi - wpływu na bieżąca działalność i zakładane kierunki rozwoju spółdzielni. W pewnym zakresie zjawisko takie było i jest dostrzegalne w spółdzielniach produkcji rolnej w związku z regulacja przyjętą w art. 139 § 2 Prawa spółdzielczego ${ }^{11}$.

Zupełnie innego rodzaju wątpliwości i zastrzeżenia budzi stworzenie w art. 3 ust. 2 ustawy z 2006 r. możliwości zakładania i przystępowania do spółdzielni socjalnych wskazanych w tym przepisie osób prawnych i jednostek organizacyjnych nielegitymujących się osobowością prawną. Ta ostatnia możliwość przełamuje utrwaloną od 1994 r. zasadę dostępności członkostwa w spółdzielniach wyłącznie dla osób fizycznych i prawnych w granicach i na

\footnotetext{
${ }^{9}$ Por. art. 2 ust. 2 pkt 1 i 2 ustawy o spółdzielniach socjalnych.

${ }^{10}$ Należy założyć, że nie dotyczy to osób wskazanych w art. 4 ust. 1 ustawy, a ich zatrudnienie oparte jest na jednej z umów o pracę przewidzianych w art. $25 \S 1$ Kodeksu pracy.

11 Stosownie do powołanego przepisu członkami spółdzielni produkcji rolnej moga poza rolnikami być również inne osoby mające kwalifikacje przydatne do pracy w spółdzielni.
} 
warunkach uregulowanych w ustawie. Z punktu widzenia przejrzystości konstrukcyjnej, wspomniane odstępstwo nie wydaje się pożądane. Chodzi głównie o to, że może stanowić swoistą furtkę dla kolejnych propozycji legislacyjnych adresowanych do innych typów spółdzielni. Spółdzielnie socjalne są w istocie swoistym rodzajem spółdzielni pracy. Jednoznacznie dowodzi tego identyczne oznaczenie przedmiotu działalności gospodarczej spółdzielni pracy w art. 181 Prawa spółdzielczego i spółdzielni socjalnej w art. 2 ust. 1 ustawy z 2006 r. ${ }^{12} \mathrm{Ze}$ względów zupełnie oczywistych zarówno osoby prawne, jak i jednostki organizacyjne bez atrybutu osobowości prawnej nie moga osobiście świadczyć pracy. Ta okoliczność jednoznacznie wyklucza możliwość nabycia przez nie członkostwa w spółdzielni pracy. W wypadku natomiast spółdzielni socjalnych obowiązek osobistego świadczenia pracy w oparciu o spółdzielczą umowę o pracę został uchylony na podstawie art. 5 ust. 7 ustawy z 2006 r. Swoisty substytut obowiązku osobistego świadczenia pracy w spółdzielniach socjalnych przez podmioty wskazane w art. 4 ust. 2 ustawy z 2006 r. ma polegać w szczególności na przeniesieniu własności lub obciążeniu rzeczy albo praw oraz dokonywaniu innych świadczeń na rzecz spółdzielni. Wspomniane świadczenia ze strony organizacji pozarządowych, kościelnych osób prawnych czy jednostek samorządu terytorialnego mogą być dokonywane jedynie na rzecz spółdzielni socjalnych, których były założycielami (współzałożycielami).

Jedną z podstawowych zasad spółdzielczych wyraźnie eksponowanych $\mathrm{w}$ ustawowych definicjach spółdzielni ${ }^{13}$ jest nieograniczony charakter dostępności członkostwa dla osób spełniających wymagania statutowe. Zasada powyższa, znana w doktrynie prawa spółdzielczego i w praktyce spółdzielczej jako zasada „drzwi otwartych” ${ }^{14}$, nie ma jednak charakteru bezwzględnego. Z przyczyn natury faktycznej uzasadnione jest ograniczenie liczebności członków spółdzielni przez odmowę przyjmowania kolejnych zainteresowanych. Tak na przykład usprawiedliwiona jest odmowa przyjęcia do spółdzielni pracy $\mathrm{z}$ powodu braku miejsc pracy lub nieposiadania przez zainteresowanego kwalifikacji zawodowych wymaganych ze względu na charakter prowadzonej działalności gospodarczej. Podobnie spółdzielnia mieszkaniowa, która definitywnie zakończyła działalność inwestycyjną ${ }^{15}$, odmówi przyjęcia nowych członków ze względu na faktyczną niemożność spełnienia ich oczekiwania dotyczącego lokalu mieszkalnego lub użytkowego. Jednakże dotychczasowe ustawodawstwo spółdzielcze nie znało przypadku ustawowego ograniczenia liczebności członków danego typu spółdzielni czy też upoważnienia statutów spółdzielni do określania maksymalnej liczby członków danej spółdzielni.

${ }^{12}$ W konsekwencji statuty typowych spółdzielni pracy nie moga przewidywać członkostwa dla osób prawnych, statuty spółdzielni socjalnych nie mogą wyłączać ich członkostwa, ale tylko dla osób prawnych określonych w art. 4 ust. pkt 2 i 3 ustawy z 2006 r.

${ }^{13}$ Por. art. 1 ustawy z 29 października 1920 r. o spółdzielniach (Dz. U. R. P. Nr 111, poz. 733); art. 1 ustawy z 17 lutego 1961 r. o spółdzielniach i ich związkach (Dz. U. 1961, Nr 12, poz. 61 z późn. zm.) oraz art. $1 \S 1$ obowiązującego Prawa spółdzielczego.

${ }^{14}$ Por. np. M. Gersdorf, J. Ignatowicz, Prawo spótdzielcze. Komentarz, Warszawa 1985, s. 17-18; L. Stecki, Prawo spótdzielcze, Warszawa 1987, s. 11; Z. Niedbała, Zagadnienia prawa spótdzielczego, Poznań 1991, s. 13 oraz idem, Prawo spótdzielcze, Poznań 2001, s. 16-17.

15 Oznacza to faktyczną niemożność zawierania przez spółdzielnię mieszkaniową umów o budowę, a następnie umów ustanawiających na rzecz członka jednego z tytułów prawnych do lokalu mieszkalnego. 
Zasadniczego wyłomu w podejściu do zasady „drzwi otwartych” dokonano dopiero $\mathrm{w}$ ustawie o spółdzielniach socjalnych. Wynika to jednoznacznie $\mathrm{z}$ art. 5 ust. 2 ustawy z 2006 r., zgodnie z którym spółdzielnia socjalna może liczyć nie mniej niż pięciu i nie więcej niż 50 członków. Limit maksymalnej liczby członków nie dotyczy jedynie tych spółdzielni socjalnych, które powstały na skutek przekształcenia spółdzielni inwalidów lub spółdzielni niewidomych.

Rozwiązanie sztywno wyznaczające górną granicę liczebności członków spółdzielni socjalnej wydaje się co najmniej kontrowersyjne. W pewnym stopniu chodzi o to, że po raz pierwszy w polskim ustawodawstwie spółdzielczym przepis rangi ustawowej dezawuuje ideę otwartości spółdzielni. Istotniejsze jest jednak to, że w istocie bez przekonującego merytorycznego uzasadnienia zamyka drogę do członkostwa nawet dla kategorii osób wskazanych w art. 2 ust. 2 ustawy z 2006 r., jeżeli w chwili zgłaszania deklaracji członkowskich spółdzielnia socjalna osiągnęła pułap 50 członków. Jest tak nawet w sytuacji, gdy spółdzielnia ze względu na jej możliwości gospodarcze jest zainteresowana przyjmowaniem nowych członków. W zupełności nieproporcjonalną sankcję za ewentualne przekroczenie między innymi górnej liczby członków przewiduje dla spółdzielni socjalnej art. 18 pkt 2 ustawy z 2006 r. Zgodnie z powołanym przepisem we wskazanej powyżej sytuacji spółdzielnia socjalna z mocy prawa przechodzi $\mathrm{w}$ stan likwidacji ${ }^{16}$. Omawiane rozwiązanie być może byłoby w pewnym stopniu uzasadnione, gdyby ustawa z 2006 r. nakładała na państwo lub jednostki samorządu terytorialnego prawny obowiązek finansowego lub rzeczowego wspierania spółdzielni socjalnych. Z treści art. 15 ust. 1 ustawy z 2006 r. wynika jednoznacznie, że działalność spółdzielni socjalnych moż e zostać wsparta ze środków budżetu państwa lub środków jednostek samorządu terytorialnego. Szczegółowe unormowania zawarte we wspomnianym art. 15 ustawy z $2006 \mathrm{r}$. dotyczą wyłącznie sytuacji, gdy właściwe osoby administracji rządowej lub samorządowej zechca skorzystać z upoważnienia ustawowego, a ponadto jeśli w stosownych budżetach przewidziano środki na wsparcie omawianego typu spółdzielni. Odnosi się to również do pokrywania składek na ubezpieczenie emerytalne, rentowe, chorobowe i wypadkowe za zatrudnionych bezrobotnych i osoby niepełnosprawne za środków Funduszu Pracy ${ }^{17}$. Przedstawiona z konieczności nader skrótowo kwestia wymaga bezsprzecznie szerszego rozważenia. Chodzi w szczególności o to, że stopa bezrobocia jest zazwyczaj szczególnie wysoka na obszarze gmin, których dochody własne z racji skali prowadzonych na ich terenie działalności gospodarczych są relatywnie niskie $\mathrm{z}$ tytułu wpłat podatkowych. W konsekwencji zatem ewentualne obciążanie identycznym obowiązkiem wspierania spółdzielni socjalnych byłoby zabiegiem chybionym. Celowe natomiast wydaje się rozważenie możliwości przeniesienia części środków Funduszu Pracy przeznaczonego na statyczne

\footnotetext{
${ }^{16}$ Szczególnie rażąca jest sankcja przejścia spółdzielni socjalnej z mocy prawa w stan likwidacji, gdy przekroczenie górnego limitu liczby członków nastąpiło na skutek przyjęcia osób fizycznych wyraźnie w ustawie preferowanych (art. 4 ust. 1 ustawy).

17 Stosownie bowiem do art. 12 ust. 3a ustawy z 2006 r. powyższe świadczenia mogą być finansowane ze środków Funduszu Pracy przez okres i w wysokości określonej w tym przepisie na podstawie umowy zawartej z właściwym starostą.
} 
formy łagodzenia bezrobocia (zasiłki) na wspieranie inicjatyw założycielskich oraz działalność już istniejących spółdzielni socjalnych.

Członkowie spółdzielni socjalnej (osoby fizyczne) nawiązują ze spółdzielnią jako pracodawca stosunek pracy oparty $\mathrm{w}$ zasadzie na spółdzielczej umowie o pracę. W powyższej sytuacji znajduje bowiem zastosowanie art. 182 § 1 Prawa spółdzielczego ${ }^{18}$, stanowiący o obowiązku spółdzielni i jej członka pozostawania ze sobą w stosunku pracy, oraz art. 182 § 3 Prawa spółdzielczego, wskazujący spółdzielczą umowę o pracę jako podstawę tego stosunku pracy. Zgodnie z art. 12 ust. $1 \mathrm{w}$ zw. z art. 201 Prawa spółdzielczego, statut spółdzielni socjalnej może przewidywać zatrudnienie wszystkich lub niektórych członków na innej podstawie niż spółdzielcza umowa o pracę, a w szczególności na podstawie umowy o pracę nakładczą, umowę zlecenia oraz umowę o dzieło. Identyczność podstaw zatrudnienia członków w spółdzielniach pracy i w spółdzielniach socjalnych nie przekłada się jednak na unormowanie ich prawa do wynagrodzenia za pracę na rzecz spółdzielni. Odmiennie niż w spółdzielniach pracy, członkowie spółdzielni socjalnych nie partycypują w podziale nadwyżki bilansowej, czyli w części zysku spółdzielni pozostałej po pomniejszeniu o podatek dochodowy i inne obciążenia publiczno-prawne (art. 75 Prawa spółdzielczego). Wynika to jednoznacznie z art. 10 ust. 2 ustawy z 2006 r. wykluczającego dopuszczalność podziału nadwyżki bilansowej pomiędzy członków spółdzielni socjalnej zarówno poprzez przeznaczenie jej części na zwiększenie funduszu udziałowego, jak i na oprocentowanie wniesionych przez członków udziałów. Zasadniczo odmiennie niż wynagrodzenie członków spółdzielni pracy $^{19}$, wynagrodzenie członków zatrudnionych w spółdzielni socjalnej nie obejmuje prawa do udziału w nadwyżce bilansowej ${ }^{20}$. Eliminacja prawa do udziału w nadwyżce bilansowej członków spółdzielni socjalnej nie wydaje się rozwiązaniem w pełni racjonalnym. Można zgodzić się z poglądem, że w przeważającej części środki nadwyżki bilansowej przekazywane sa na fundusz zasobowy, a więc na zasilenie majątku spółdzielni i cele integracji społecznej i zawodowej (art. 2 ust. 2 ustawy z 2006 r.). Służy to bowiem wzmocnieniu podstaw rzeczowo-finansowych spółdzielni i odbudowaniu pożądanych relacji w procesie świadczenia pracy i spółdzielczej aktywności samorządowej. Odnosi się jednak wrażenie, że obowiązujące uregulowanie nazbyt pochopnie nie docenia indywidualnych motywacji natury płacowej. Z drugiej strony - członkowie spółdzielni socjalnych (w przeciwieństwie do członków nie tylko spółdzielni pracy) moga nie odczuwać bezpośredniego wpływu wypracowania nadwyżki bilansowej (udział w jej podziale) ani straty bilansowej (w jej pokryciu do wysokości zadeklarowanych udziałów).

${ }^{18}$ W razie odmowy nawiązania przez spółdzielnię socjalną z jej członkiem spółdzielczej umowy o pracę członkowi służy roszczenie nawiązania takiej umowy (art. 182 § 4 Prawa spółdzielczego w związku $\mathrm{z}$ art. $264 \S 3$ Kodeksu pracy).

${ }^{19}$ Stosownie do art. 183 Prawa spółdzielczego, wynagrodzenie członka spółdzielni pracy obejmuje zarówno wynagrodzenie bieżące, jak i udział w nadwyżce bilansowej, a oba te składniki korzystaja z ochrony prawnej, jaka prawo pracy zapewnia wynagrodzeniu pracownika (art. 84 i n. Kodeksu pracy).

${ }^{20}$ Por. art. 12 ust. 2 ustawy z 2006 r. ustalający, że prawo do wynagrodzenia przysługujące członkowi spółdzielni socjalnej nie obejmuje prawa do udziału w nadwyżce bilansowej. 
Jak już wcześniej wspomniano, współzałożycielami spółdzielni socjalnej moga być również inne osoby fizyczne niż taksatywnie wskazane w art. 4 ust. 1 ustawy z 2006 r. ${ }^{21}$ Jako założyciele spółdzielni nabywaja jej członkostwo z dniem wpisania do Krajowego Rejestru Sądowego. W konsekwencji na tych członkach oraz na spółdzielni socjalnej ciąży obowiązek nawiązania i pozostawania w stosunku pracy zazwyczaj opartym na spółdzielczej umowie o pracę, ewentualnie, gdy statut tak stanowi, na podstawach wskazanych w art. 201 $\S 1$ Prawa spółdzielczego. Ponadto spółdzielnia socjalna może zatrudniać pracowników niebędących jej członkami, z zastrzeżeniem, że liczba zatrudnionych w grupie nieczłonkowskiej nie może przekroczyć 50\% członków spółdzielni. Wspomniana grupa zatrudnianych nawiązuje ze spółdzielnią socjalną stosunki pracy na podstawie umów o pracę przewidzianych w art. 25 Kodeksu pracy. Ustawa z 2006 r. nie odsyła do art. 200 Prawa spółdzielczego ani nie zawiera regulacji podobnej do obowiązującej w spółdzielniach pracy. W tych ostatnich bowiem pracownicy zatrudnieni na podstawie umów o pracę na czas nieokreślony korzystają z roszczenia o przyjęcie do grona członkowskiego, jeżeli spełniają wymagania statutowe, a spółdzielnia ma możliwość ich dalszego zatrudnienia. Pozbawienie takiej możliwości pracowników zatrudnionych $\mathrm{w}$ spółdzielni socjalnej jest być może podyktowane niefortunnym ustawowym limitem górnej granicy 50 członków tego typu spółdzielni. Pewne preferencje dla zatrudnionych w spółdzielni pracowników niebędących członkami, jak i dla osób dotąd niezatrudnionych przez spółdzielnię, przewiduje art. 5 ust. 5 ustawy z 2006 r. Zgodnie z tym przepisem, członkostwo w spółdzielni socjalnej moga nabyć osoby inne niż wskazane w art. 4, jeżeli legitymują się kwalifikacjami zawodowymi, których nie posiadają dotychczasowi członkowie spółdzielni. Przedstawione rozwiązania nie wykluczają dopuszczalności zabiegania o członkostwo poprzez złożenie stosownej deklaracji przez pracowników spółdzielni, którzy wprawdzie nie dysponują szczególnymi kwalifikacjami, ale spółdzielnia ma gospodarczą możliwość ich dalszego zatrudnienia respektując ograniczenia ilościowe $\mathrm{z}$ art. 4 ust. 2 pkt 1 oraz z art. 5 ust. 3 i art. 12 ust. 1a ustawy. W tej ostatniej jednak sytuacji pracownik zainteresowany członkostwem, w razie odmowy przyjęcia podjętej $\mathrm{w}$ statutowym postępowaniu wewnątrzspółdzielczym, nie korzysta $\mathrm{z}$ sądowej możliwości zaskarżenia odmownej uchwały właściwego organu spółdzielni socjalnej.

\section{ORGANY I DZIAŁALNOŚĆ SPÓŁDZIELNI SOCJALNEJ}

Spółdzielnia socjalna, jak każda osoba prawna, działa przez swoje organy w sposób przewidziany w ustawie i w opartym na niej statucie (art. 38 k.c.). Przepisy ustawy z 2006 r. nie wskazują organów spółdzielni socjalnej ani nie ustalają ich kompetencji. W tym zakresie znajduje zastosowanie przepis art. 1 ust. 2 ustawy z 2006 r. wskazujacy, że w sprawach nieuregulowanych w tej

${ }^{21}$ Stosownie do art. 4 ust. 2 pkt 1 ustawy z 2006 r. liczba takich osób nie może stanowić więcej niż $50 \%$ ogólnej liczby założycieli spółdzielni socjalnej. 
ustawie stosuje się przepisy Prawa spółdzielczego ${ }^{22}$. W konsekwencji zatem organami spółdzielni socjalnej w myśl art. 35 § 1 Prawa spółdzielczego są: walne zgromadzenie, rada nadzorcza i zarząd spółdzielni. Identycznie też walne zgromadzenie korzysta $\mathrm{z}$ wyłącznych kompetencji wskazanych $\mathrm{w}$ art. $38 \S 1$, a rada nadzorcza - z kompetencji wskazanych w art. 46 § 1 Prawa spółdzielczego $\mathrm{z}$ zastrzeżeniem możliwości pewnych zmian $\mathrm{w}$ zakresie określonym odpowiednio $\mathrm{w}$ art. 38 \$ 2 i art. 46 § 2 Prawa spółdzielczego w statucie spółdzielni socjalnej. Istotną odrębnością w spółdzielniach socjalnych jest jednak możliwość rezygnacji z rady nadzorczej. Stosownie do art. 7 ust. 2 ustawy z 2006 r. tego rodzaju możliwość dotyczy tylko spółdzielni socjalnych, w których liczba członków nie przekracza piętnastu. W wypadku statutowej rezygnacji z rady nadzorczej, kompetencje ustawowe tego organu wykonuje walne zgromadzenie spółdzielni socjalnej. W poprzedzającym ustawę z $2006 \mathrm{r}$. unormowaniu działalności i organizacji socjalnych (art. 203b § 3 Prawa spółdzielczego) dodatkowo wskazano, że w razie braku rady nadzorczej prawo kontroli działalności socjalnej przysługuje każdemu członkowi. Nie można jednak uznać, że obecna regulacja pozbawia członków spółdzielni socjalnej (w tym również o licznie członków mniejszej niż 15) instrumentów kontroli działalności spółdzielni. Członkowie wszystkich spółdzielni, w tym również spółdzielni socjalnych, korzystają bowiem z wszystkich uprawnień kontrolnych przewidzianych $\mathrm{w}$ art. 18 Prawa spółdzielczego oraz innych przepisach ustawowych i w statucie spółdzielni. Warto też zwrócić uwagę, że w przeciwieństwie do unormowania uprzednio obowiązującego (art. 203b § 3 Prawa spółdzielczego), obecnie obowiązujący art. 7 ust. 2 ustawy z 2006 r. wybór i funkcjonowanie rady nadzorczej w mniejszych spółdzielniach socjalnych (do 15 członków) pozostawia regulacji przyjętej w statucie tego typu spółdzielni ${ }^{23}$.

Działalność spółdzielni socjalnych ma przede wszystkim służyć reintegracji społecznej i zawodowej jej członków. Działania spółdzielni zmierzające do realizacji powyższych celów „,nie są wykonywane w ramach prowadzonej przez spółdzielnię socjalną działalności gospodarczej" (art. 2 ust. 1 in fine ustawy z 2006 r.). Osiaganie celów reintegracyjnych powinno zatem odbywać się w sferze pozagospodarczej aktywności spółdzielni socjalnej. Przedstawione rozwiązanie przyjęte w ustawie z $2006 \mathrm{r}$. budzi istotne wątpliwości i zastrzeżenia. Chodzi przede wszystkim o dwie podstawowe kwestie. Spółdzielnia socjalna prowadzi wspólną działalność gospodarczą w formie przedsiębiorstwa w oparciu o osobista pracę jej członków. Wspólna, skooperowana praca wydaje się najbardziej efektywną płaszczyzną zawodowej reintegracji osób dotąd bezrobotnych oraz osób niepełnosprawnych. Ponowna integracja tych grup członków, zarówno w aspekcie zawodowym, jak i społecznym poza praca, na rzecz wspólnie prowadzonego przedsiębiorstwa może być jedynie działaniem uzupełniającym, wspomagającym osiagganie celów ustawowych (art. 2 ust. 2

\footnotetext{
${ }^{22}$ Należy zwrócić uwagę, że art. 1 ust. 2 ustawy z 2006 r. wskazuje na stosowanie w sprawach w niej nieuregulowanych przepisów Prawa spółdzielczego wprost, bez zastrzeżenia stosowania ich „,odpowiednio".

${ }^{23}$ Uprzednio obowiązujący art. 203b § 3 Prawa spółdzielczego jednoznacznie wykluczał powołanie rady nadzorczej w spółdzielniach socjalnych, w których liczba członków nie przekraczała 15.
} 
pkt 1 i 2 ustawy z 2006 r.). Powołana ustawa, identycznie jak art. 1 § 2 Prawa spółdzielczego, prowadzenie działalności poza gospodarczej przez spółdzielnię socjalną pozostawia rozwiązaniom statutowym. Stosownie do art. 2 ust. 3 ustawy z 2006 r. spółdzielnia socjalna może prowadzić działalność społeczna i oświatowo-kulturalną na rzecz swoich członków oraz ich lokalnego środowiska $^{24}$. Prawo spółdzielcze w rezultacie nowelizacji dokonanej w 1994 r. zrezygnowało z kontynuowania wcześniej obowiązującej zasady równorzędności obu nurtów aktywności spółdzielni: działalności gospodarczej i działalności społecznej wraz z oświatowo kulturalną ${ }^{25}$. Wprowadzona w 1994 r. fakultatywność prowadzenia przez spółdzielnie działalności pozagospodarczej podyktowana była obawami praktyki spółdzielczej, że obowiązek wykonywania tej działalności o charakterze niedochodowym zdecydowanie osłabi konkurencyjność spółdzielni na rynku towarów i usług. Tego rodzaju argumentacja nie wydaje się jednak przekonująca w odniesieniu do spółdzielni socjalnych. Nietrudno bowiem dostrzec, że korzystając z określenia działalności pozagospodarczej - jako fakultatywnej w art. 2 ust. 3 ustawy z 2006 r. - autorzy statutów omawianych spółdzielni zrezygnują z prowadzenia tej działalności. W takich sytuacjach realizacja ustawowych zadań reintegracyjnych poza nurtem prowadzonej przez spółdzielnię działalności gospodarczej staje się w istocie fikcją. Dostrzegalna wydaje się zatem wewnętrzna sprzeczność pomiędzy celami integracyjnymi ustawy a przewidzianymi do ich realizacji instrumentami. W szczególności chodzi o swoistą ustawową dyskwalifikację zorganizowanej, wspólnej pracy jako czynnika integrującego.

Jak już wcześniej wspomniano, spółdzielnie socjalne moga korzystać ze wsparcia finansowego oraz innego rodzaju świadczeń ze strony budżetu państwa oraz budżetów jednostek samorządu terytorialnego. Regulacja przyjęta w art. 15 ustawy z 2006 r. nie stanowi jednak dla państwa i jednostek samorządu terytorialnego obowiązku wspierania działalności socjalnych, a dla tych ostatnich nie stanowi podstawy roszczenia o udzielenie wsparcia $\mathrm{w}$ formach przewidzianych w powołanym przepisie. Zasady i wysokość omawianego wsparcia udzielana być może w granicach określonych w uchwale właściwego organu samorządowego lub ministerialnego programu ustalanego zgodnie z przepisami ustawy o pomocy społecznej ${ }^{26}$. Ponadto na podstawie umowy zawartej ze starostą spółdzielnia może uzyskać refundację kosztów pracy (wynagrodzenia za pracę, składki na ubezpieczenie emerytalno-rentowe i wypadkowe) w wysokości i przez okres określony w art. 12 ust. 3a i n. ustawy z 2006 r. Formą wsparcia dla założycieli lub osób przystępujących do spółdzielni socjalnych moga być poręcznie pożyczek kredytów lub zabezpieczenia zwrotu środków na założenie lub przystąpienie do spółdzielni ze strony jednostek

\footnotetext{
${ }^{24}$ Stosownie do art. 2 ust. 3 ustawy z 2006 r., o ile statut spółdzielni socjalnej przewiduje również prowadzenie działalności poza gospodarczej, może ona obejmować również działanie społecznie użyteczne w sferze zadań publicznych określonych w ustawie o działalności pożytku publicznego i o wolontariacie.

${ }^{25}$ Por. M. Gersdorf, J. Ignatowicz, op. cit., s. 18-19; Z. Niedbała, Komentarz do znowelizowanego prawa spótdzielczego..., s. 8-9.

${ }^{26}$ Por. ustawę z 12 marca 2004 r. o pomocy społecznej (tekst jedn.: Dz. U. 2009, Nr 175, poz. 1362 z późn. zm.).
} 
samorządu terytorialnego, kościelnych osób prawnych lub organizacji pozarządowych ${ }^{27}$. Natomiast świadczenia ze strony wolontariuszy na rzecz spółdzielni moga dotyczyć wyłącznie prowadzonej przez spółdzielnię działalności pożytku publicznego ${ }^{28}$. Formą wsparcia finansowego działalności spółdzielni socjalnej są też środki funduszu udziałowego, a więc funduszu tworzonego z wpłat udziałów członkowskich obowiązkowych, jak i nadobowiązkowych. Wspomniane źródło wsparcia ma jednak bardzo ograniczone znaczenie. W pierwszym rzędzie z tego względu, że wysokość obligatoryjnych udziałów członkowskich, szczególnie ze strony członków wskazanych w art. 4 ust. 1 ustawy z 2006 r., ze zrozumiałych powodów jest raczej symboliczna. Z drugiej strony wynika to z ustawowego zakazu przeznaczania części nadwyżki bilansowej spółdzielni socjalnej na zwiększenie jej funduszu udziałowego ${ }^{29}$.

Zaprezentowany wyżej obraz skali i charakteru instrumentów wspierania procesów założycielskich oraz podjętej przez spółdzielnię socjalną działalności nie skłania do zbyt optymistycznych konkluzji. Chodzi w szczególności o generowanie miejsc pracy dla osób dotąd bezrobotnych oraz skłonnych i zdolnych do pracy osób niepełnosprawnych, a nadto ich reintegrację społeczną i zawodową. O ile można zrozumieć, że możliwości budżetu państwa i budżetów samorzadowych na łagodzenie skutków bezrobocia i aktywizację osób niepełnosprawnych sa ograniczone, o tyle można odnieść wrażenie, że wykorzystanie tych środków dokonywane jest głównie za pomoca instrumentów statycznych (na przykład zasiłki czy szkolenie zawodowe nader często rozmijające się z potrzebami lokalnego rynku pracy).

\section{PRZEKSZTALCENIA ORGANIZACYJNE I LIKWIDACJA SPÓŁDZIELNI SOCJALNYCH}

Przyjmując, że przekształcenia organizacyjne obejmuja łączenie, podział, a także zmianę statusu spółdzielni na status spółki handlowej, to możliwości prawne spółdzielni socjalnych na tle innych typów spółdzielni są zdecydowanie ograniczone. Stosownie do art. 16 ustawy z 2006 r., spółdzielnia socjalna może łączyć się wyłącznie z inną (innymi) spółdzielnią socjalną. Ze względu na odesłanie zawarte w art. 1 ust. 2 wspomnianej ustawy, zasady i tryb łączenia spółdzielni socjalnych określaja przepisy art. 96-102 Prawa spółdzielczego. Istotne wątpliwości powstaja jednak $\mathrm{w}$ sytuacji, gdy $\mathrm{w}$ efekcie połączenia przejmująca spółdzielnia socjalna przekroczy limit 50 członków, ponieważ w chwili połączenia członkowie spółdzielni przejmowanej stają się z mocy prawa członkami socjalnej spółdzielni przejmującej. De lege lata w powyższym przypadku już w momencie połączenia spółdzielnia socjalna przejmująca

\footnotetext{
${ }^{27}$ Dotyczy to jednak wyłącznie osób wskazanych w art. 4 ust. 1 ustawy, które zostały zatrudnione w spółdzielni socjalnej założonej przez organizacje pozarządowe, kościelne osoby prawne i jednostki samorządu terytorialnego.

${ }^{28}$ Por. art. $14 \mathrm{w}$ zw. z art. 5a $\$ 5$ ustawy z 2006 r.

${ }^{29}$ Por. art. 10 ust. 2 ustawy z 2006 r.
} 
przejdzie z mocy prawa $\mathrm{w}$ stan likwidacji ${ }^{30}$. W praktyce niejednokrotnie może okazać się, że uzasadniony względami ekonomicznymi, organizacyjnymi i społecznymi zabieg inkorporacyjny prowadzi do efektu zgoła niepożądanego, a ściślej: likwidacji połączonej spółdzielni socjalnej. Tego rodzaju potencjalne zagrożenie jest kolejnym argumentem podważającym celowość i zasadność ustalenia ustawowego górnego limitu członków spółdzielni socjalnej.

Spółdzielnia socjalna może ulec podziałowi na podstawie uchwały walnego zgromadzenia podjętej kwalifikowaną większością 2/3 głosów przy zachowaniu quorum co najmniej połowy uprawnionych do głosowania, chyba że jej statut zawiera odmienne postanowienie w kwestii quorum ${ }^{31}$. Stosownie do art. 17 ust. 2 ustawy z 2006 r., w wyniku takiego podziału moga być utworzone wyłącznie spółdzielnie socjalne. Wspomniana ustawa nie wymaga natomiast spełnienia określonych przesłanek merytorycznych dla przeprowadzenia podziału. Tryb przeprowadzenia podziału spółdzielni socjalnej określają przepisy art. 108 i n. Prawa spółdzielczego. Nie ulega wątpliwości, że uchwała podziałowa walnego zgromadzenia powinna zawierać wszystkie elementy wskazane w art. $108 \S 2$ Prawa spółdzielczego. Wątpliwości budzi możliwość podziału spółdzielni w szczególnym trybie przewidzianym w art. 108a i 108b Prawa spółdzielczego, a więc gdy inicjatorami podziału są członkowie spółdzielni, których prawa i obowiązki majątkowe sa związane $\mathrm{z}$ wyodrębniona jednostką organizacyjną spółdzielni albo częścią jej majątku nadająca się do takiego wyodrębnienia. Chodzi tu w szczególności o te spółdzielnie socjalne, których zakładanie i późniejsza działalność w całości lub w części wspierana była ze środków publicznych. W takiej bowiem sytuacji co najmniej wątpliwe byłoby wskazanie praw majątkowych inicjatorów podziału do części majątku spółdzielni socjalnej. Tworzenie nowych spółdzielni socjalnych poprzez podział dotychczasowej spółdzielni musi również mieć na względzie zagrożenie wynikające $\mathrm{z}$ art. 18 pkt 2 ustawy z 2006 r. O ile bowiem w efekcie podziału spółdzielnia podlegająca podziałowi lub tworzona $\mathrm{w}$ tym trybie zmniejszy liczbę członków poniżej 5 $\mathrm{z}$ mocy prawa przechodzi $\mathrm{w}$ stan likwidacji. Warto zwrócić uwagę, że w porównaniu z art. $113 \S 1$ pkt 2 Prawa spółdzielczego ustawa z 2006 r. nie przewiduje rocznej karencji umożliwiającej zwiększenie liczby członków do wymaganej.

Spółdzielnia socjalna może powstać również w wyniku przekształcenia w ten sam typ spółdzielni dotychczasowej spółdzielni inwalidów albo spółdzielni niewidomych. Ani Prawo spółdzielcze, ani ustawa z 2006 r. nie zawieraja żadnych bliższych regulacji określających warunki, zasady i tryb takiego przekształcenia. $\mathrm{O}$ ile zatem statut spółdzielni inwalidów lub spółdzielni niewidomych nie zawiera $\mathrm{w}$ tym zakresie stosownych postanowień na zasadzie analogii do art. $108 \S 1 \mathrm{w}$ zw. z art. $41 \S 2$ Prawa spółdzielczego, można przyjąć, że uchwałę w sprawie przekształcenia podejmuje walne zgromadzenie zwykłą

\footnotetext{
${ }^{30}$ Skutek przejścia w stan likwidacji z mocy prawa nie dotyczy tylko przekształcenia dotychczasowej spółdzielni inwalidów lub niewidomych w spółdzielnię socjalną.

${ }^{31}$ Taką możliwość odmiennego unormowania wymogu quorum przewiduje art. $41 \S 2$ Prawa spółdzielczego.
} 
większościa głosów w obecności co najmniej 50\% uprawnionych do głosowania. Jeżeli w wyniku omawianego przekształcenia powstała spółdzielnia socjalna zrzeszająca więcej niż 50 członków, nie ma zastosowania limit z art. 5 ust. 2 oraz sankcja przejścia $\mathrm{w}$ stan likwidacji z art. 18 pkt 2 ustawy z $2006 \mathrm{r}$. Jak już wspomniano, art. 1 ust. 2 ustawy z 2006 r. w sprawach w niej nieuregulowanych odsyła do przepisów Prawa spółdzielczego. Należy przyjąć, że odesłanie to dotyczy przede wszystkim części I Prawa spółdzielczego: „,Spółdzielnie”, w tym również odrębnej regulacji obejmującej spółdzielnie pracy.

$\mathrm{Z}$ dniem 1 lipca $2011 \mathrm{r}$. weszły w życie przepisy art. 2 pkt 4 ustawy z 25 marca 2011 r. o ograniczaniu barier administracyjnych dla obywateli i przedsiębiorców ${ }^{32}$, które stały się integralną częścią Prawa spółdzielczego, a znalazły wyraz w nowym Dziale VI (art. 203e-203x ustawy z 16 września 1982 r.) ${ }^{33}$. Wspomniane ostatnio przepisy reguluja nieznaną uprzednio ustawodawstwu spółdzielczemu instytucję przekształcenia spółdzielni pracy w spółkę handlową. Problem przekształcania spółdzielni w spółki prawa handlowego już od dłuższego czasu budził sporo kontrowersji i wątpliwości w doktrynie. Orzecznictwo sądowe, początkowo aprobujące dopuszczalność tego rodzaju przekształceń, w ostatnich latach wyraźnie opowiadało się przeciwko prawnej dopuszczalności omawianych przekształceń. Analiza przepisów art. 203e i n. Prawa spółdzielczego na tle dotychczasowej doktryny i orzecznictwa wykracza jednak poza ramy niniejszej wypowiedzi. Wspomniane ostatnio przepisy wyraźnie wskazuja jedynie na spółdzielnie pracy jako objęte możliwością przekształcenia w spółkę handlową. Zarówno Prawo spółdzielcze, jak i ustawa z 2006 r. nie wskazuja wprost spółdzielni socjalnych, ale też nie wyłączają ich z kręgu uprawnionych do przekształcenia. Wydaje się jednak, że ze względu na źródła finansowania procesu założycielskiego tych spółdzielni oraz wsparcia działalności ze strony Funduszu pracy spółdzielnie socjalne nie spełniają warunków dla przekształcania w spółki prawa handlowego. Na tle art. 19 ust. 2 ustawy z 2006 r. można jedynie rozważać możliwość omawianego przekształcenia, ale wyłącznie przy wykorzystaniu tak zwanej ścieżki likwidacyjnej ${ }^{34}$.

Podobnie jak wszystkie inne typy spółdzielni, również spółdzielnia socjalna przechodzi $\mathrm{w}$ stan likwidacji zarówno $\mathrm{z}$ inicjatywy jej członków wyrażonej w stosownych uchwałach walnego zgromadzenia ${ }^{35}$, jak i z mocy prawa na skutek zdarzeń wskazanych w ustawie. Porównanie art. $113 \S 1$ Prawa spółdzielczego, określającego zdarzenia powodujące przejście w stan likwidacji ogółu spółdzielni, z katalogiem takich zdarzeń w przypadku spółdzielni socjalnych bezsprzecznie wskazuje na przesadny rygoryzm wobec tych ostatnich. Już wcześniej krytycznie oceniono przejście spółdzielni socjalnej w stan likwidacji w razie przekroczenia górnego limitu jej członków (tj. 50). Tak samo krytycznie można odnieść się do przyczyny likwidacji, którą jest zaprzestanie

${ }^{32}$ Dz. U. 2011, Nr 106, poz. 622.

${ }^{33}$ Zarówno tytuł Działu VI oraz jego nazwa („Przekształcenia spółdzielni pracy”) wyraźnie wskazuja, że nie dotyczy on innych typów spółdzielni.

${ }^{34} \mathrm{Tj}$. w trybie art. $125 \S 5$ a Prawa spółdzielczego.

${ }^{35}$ Por. art. 1 ust. 7 ustawy o spółdzielniach mieszkaniowych w zw. z art. $113 \S 1$ pkt 3 Prawa spółdzielczego. 
przez nią używania w nazwie oznaczenia ,,spółdzielnia socjalna”. Wydaje się, że bardziej racjonalna byłaby $\mathrm{w}$ przedstawionych przypadkach reakcja sądu rejestrowego wyznaczającego spółdzielni socjalnej stosowny termin do przywrócenia stanu zgodnego $\mathrm{z}$ prawem $\mathrm{z}$ zastrzeżeniem rygoru postawienia jej w stan likwidacji po bezskutecznym upływie wyznaczonego terminu.

Ustawę z 2006 r. wraz ze zmianami z 2009 i 2010 r. można z pewnościa zaliczyć do kategorii rozwiązań prawnych służących łagodzeniu skutków bezrobocia i aktywizacji zawodowej osób niepełnosprawnych czy z innych względów mających mniejsze szanse zatrudnienia. Stąd zrozumiałe i zasadne sa wyraźne preferencje dla tych grup osób w zakresie zakładania oraz przyjmowania do spółdzielni socjalnej i zatrudnienia w spółdzielni. Z drugiej jednak strony, nadmierna wydaje się kazuistyka przepisów ustawy posługującej się licznie sztywnymi limitami liczebności członków, osób zatrudnianych bez statusu członkowskiego, czy też ostatnio wspomnianego katalogu zdarzeń stawiających spółdzielnię socjalną w stan likwidacji, tym bardziej że skala ulg i form finansowego wsparcia ze środków publicznych dla tych spółdzielni jest nader skromna. Można sądzić, że w wielu przypadkach sztywne, rygorystyczne rozwiązania ustawowe można było zastąpić odesłaniem do statutów spółdzielni socjalnych, określając jedynie ogólne warunki unormowań statutowych.

prof. dr hab. Zdzistaw Niedbata

Uniwersytet im. Adama Mickiewicza w Poznaniu

\title{
A SOCIAL CO-OPERATIVE AS A FORM OF MITIGATING THE EFFECTS OF UNEMPLOYMENT AND ACTIVISATION OF THE DISABLED
}

\author{
Summary
}

\begin{abstract}
Reduction of unemployment or mitigation of its effects requires different economic, legal, or organisational instruments and may take different forms as well. The legal regulations available since 2004 include, inter alia, an institution of a social co-operative. The principles on which such a co-operative is to be organised and may function are set forth in the Act of 27 April 2006 on social co-operatives, substantially amended in 2010. Its provisions create preferential conditions for the unemployed, the disabled, and those entitled to social employment to set up, and be members of, social cooperatives. The paper contains a detailed analysis of the preferences as well as the forms of financial support available from public funds to social co-operatives. Those statutory solutions which are too rigid with regards e.g. the limited membership or employment in social co-operatives are being criticised, and the suggestion with which the paper ends calls for a wider application of those statutory provisions which allow to more accurately and more effectively account for the local needs and conditions, and make better use of the support of the units of local self-government.
\end{abstract}


